\title{
Typing of Staphylococcus aureus strains by PCR-amplification of variable-length 16S-235 rDNA spacer regions: characterization of spacer sequences
}

\author{
Volker Gürtler and Helen D. Barrie \\ Author for correspondence: V. Gürtler. Tel: +613496 2743. Fax: +61 34962178. \\ e-mail: volker@austin.unimelb.edu.au
}

Department of

Microbiology, Heidelberg

Repatriation Hospital,

Heidelberg West 3081,

Victoria, Australia

Keywords: Stapbylococcus aureus, typing, rDNA, rrn operon, spacer regions

\section{INTRODUCTION}

Disease caused by Staphylococcus aureus is often the result of hospital-acquired (nosocomial) infections. Strains of $S$. aureus that are resistant to the penicillinase-resistant antibiotic methicillin are now common, the first major nosocomial epidemic of a methicillin-resistant strain of $S$. aureus (MRSA) having been described by Stewart \& Holt (1963). The determination of whether isolates of $S$. aureus represent a single strain is of considerable epidemiological value in a hospital setting.

Numerous methods for typing MRSA isolates have been described, including bacteriophage typing (Blair \&

Abbreviations: HRH, Heidelberg Repatriation Hospital; MASA, methicillin-resistant Staphylococcus aureus; RFLP, restriction fragment length polymorphism.

The GenBank accession numbers for the sequences reported in this paper are U11773-U11789.
Williams, 1961), biotyping (Cookson et al., 1986), electrophoretic protein typing (Costas et al., 1989; Stephenson et al., 1986), immunoblots (Mulligan et al., 1988), plasmid DNA analysis (Hartstein et al., 1989), multilocus enzyme electrophoresis (Musser \& Kapur, 1992), ribotyping (see below), analysis of the mec gene (Kreiswirth et al., 1993) and pulsed-field gel electrophoresis (Prevost et al., 1991; Wei \& Grubb, 1992).

The 16S rRNA gene has been used extensively for evolutionary studies of bacterial species (Woese, 1987) and the rRNA operon has been used for evolutionary studies of bacterial strains (Gürtler, 1993; Frothingham \& Wilson, 1993). The Southern hybridization of rRNA operons to detect restriction fragment length polymorphisms (RFLPs) between MRSA strains has been reported (Blumberg et al., 1992; De Buyser et al., 1992; Monzon et al., 1991; Preheim et al., 1991). However, Southern hybridization is slow and labour-intensive. The rRNA RFLPs found in Clostridium difficile have been 
shown in part to be due to variable-length $16 \mathrm{~S}-23 \mathrm{~S} \mathrm{rDNA}$ spacer regions (Gürtler, 1993). A method was described to type $C$. difficile strains based on the variable-length 16S-23S rDNA spacer regions (Gürtler, 1993). In this report an identical approach is used to type $S$. aureus isolates.

The number of rRNA operons has been completely determined (by Southern hybridization or PCR of the rDNA) in only a few eubacteria, including Escherichia coli, where there are seven operons (Morgan et al., 1977); Bacillus subtilis, 10 operons (Loughney et al., 1982); Clostridium perfringens, 10 operons (Garnier et al., 1991); C. difficile, 10 operons (Gürtler, 1993); and Mycobacterium spp. (Bercovier et al., 1986) and Mycoplasma spp. (Amikam et al., 1984), one and two operons respectively. The reports describing sequence data for the $16 \mathrm{~S}-23 \mathrm{~S}$ spacer region are so far incomplete: of seven operons in E. coli five spacers have been sequenced (Harvey et al., 1988); in B. subtilis two of 10 spacers have been sequenced (Loughney et al., 1982); in Plesiomonas shigelloides three spacers (East et al., 1992); in Aeromonas bydrophila three spacers (East \& Collins, 1993) and in Caulobacter crescentus (Feingold et al., 1985), Acholeplasma laidlawii (Nakagawa et al., 1992) and Enterococcus birae (Sechi \& Daneo-Moore, 1993) two spacers have been sequenced. In this report we describe for the first time the 16S-23S spacer sequences for the complete rRNA operon set in $S$. aureus.

\section{METHODS}

Bacterial strains and their cultivation. The bacterial strains used are listed in Table 1. The identity of all strains was determined by biochemical tests (Kloos \& Schleifer, 1986), and antibiotic sensitivity tests were assessed by the agar dilution method (break points were determined according to NCCLS guidelines, vol. 13, no. 25, 1993). Purified stocks were stored in glycerol broth at $-70^{\circ} \mathrm{C}$. All strains were grown in trypticase soya broth (TSB, Oxoid). The stability of ribotype patterns was tested by passaging single colonies from sheep blood agar plates five times a week for six weeks.

DNA isolation and amplification. Genomic DNA was isolated by the protocol of Gürtler et al. (1991) except that the cell walls of $S$. aureus were disrupted by incubating the strain with $200 \mu \mathrm{g}$ lysostaphin $\mathrm{ml}^{-1}$ at $37^{\circ} \mathrm{C}$ for 5-10 min. DNA regions (Fig. 1) were amplified by the protocol of Gürtler (1993) using the primers shown in Table 2. For the amplification of M13 clone inserts, $50-100 \mathrm{ng}$ single-stranded M13 clone DNA was added to PCR mixtures using primers $\mathrm{M} 13 \mathrm{~F}$ and $\mathrm{R}$.

Restriction enzyme analysis. PCR product M13F-M13R was digested with $10-15$ units DraI or Hinfl, as instructed by the manufacturer (Boehringer). Genomic DNA was digested with 20 units HpaII. The digested PCR products and genomic DNA were resolved on $2 \%(\mathrm{w} / \mathrm{v})$ low-gelling-temperature plus $2 \%$ (w/v) 'AR' agarose gels.

Southern hybridization. The protocol of Gürtler et al. (1991) was followed to hybridize digoxigenin-labelled PCR products I and J (Fig. 1: amplified using V42 and V12, respectively, as templates) to $S$. aureus genomic DNA.

Denaturing PAGE. $\left[{ }^{33} \mathrm{P}\right] \mathrm{dATP}$-labelled PCR product $\mathrm{C}$ was amplified and electrophoretically separated by the protocol of Gürtler (1993).

\section{Table 1. S. aureus strains}

The numbers of strains isolated from various locations at various times are shown. The strains from Ireland are listed in Townsend et al. (1987) as WG1761-3 (plus six other strains) while those from RFH are listed in Townsend $e$ al. (1984) as WG2710, 2715, 2720 and 2724 and in Townsend et al. (1987) as WG2716 (plus three other strains).

\begin{tabular}{|llc|}
\hline Location* & Year & $\begin{array}{c}\text { No. of } \\
\text { isolates }\end{array}$ \\
\hline Methicillin-resistant & & \\
Guildford, UK, NCTC 10442 & 1960 & 1 \\
New York, ATCC 33952 & 1981 & 1 \\
Melbourne, RMH & 1982 & $10 \dagger$ \\
UK, NCTC 11940 & 1982 & 1 \\
UK, NC'TC 11939 & 1982 & 1 \\
Melbourne, HRH & 1982 & $6 \ddagger$ \\
Ireland & $1982-83$ & 9 \\
London, RFH & 1983 & 8 \\
London, NCTC 12232 & 1986 & 1 \\
Melbourne, HRH & $1988-9$ & 7 \\
Melbourne, HRH & $1992-1993$ & $226 \S$ \\
Melbourne, RCH & 1993 & 3 \\
Penicillin-sensitive & & \\
HRH & $1992-4$ & 14 \\
Oxford, UK, ATCC 9144 & 1944 & 1 \\
Bundaberg, Australia, NCTC 2669 & 1928 & 1 \\
UK, NCTC 8532 & 1953 & 1 \\
Methicillin-sensitive & & \\
HRH & $1992-3$ & 31 \\
\hline
\end{tabular}

* NCTC, National Collection of Type cultures, UK; ATCC, American Type Culture Collection; HRH, Heidelberg Repatriation Hospital; RMH, Royal Melbourne Hospital; RCH, Royal Children's Hospital, Melbourne; RFH, Royal Free Hospital, London, UK.

† Including $\mathrm{H} 21$.

$\ddagger$ Including H11, H12, H14.

Including D46.

Cloning. PCR product C (Fig. 1) was amplified (described above) from $S$. aureus genomic DNA from strains D46, H11 and ATCC 33952 using primers R1391F and LR488,R1391FH and LR488H, or R1391F and LR194F (Table 2). For each strain, ten equivalent reactions were pooled, precipitated with $26 \%$ (w/v) polyethylene glycol in $20 \mathrm{mM} \mathrm{MgCl}$ (Paithankar \& Prasad, 1991) and digested with HpaII. For D46, $1 \mu \mathrm{g}$ of the HpaIIdigested products was end-repaired with 4 units of T4 DNA polymerase (Boehringer), $200 \mu \mathrm{M}$ dNTPs, $33 \mathrm{mM}$ Tris/acetate ( $\mathrm{pH} 8.0$ ), $66 \mathrm{mM}$ potassium acetate, $10 \mathrm{mM}$ magnesium acetate, $0.5 \mathrm{mM}$ dithiothreitol, $0.1 \mathrm{mg}$ bovine serum albumin $\mathrm{ml}^{-1}$ and incubated at $11^{\circ} \mathrm{C}$ for $30 \mathrm{~min}$. For ATCC 33952 and $\mathrm{H} 11$ the HpaII-digested products (1-25 ng) were ligated directly into AccI-digested M13mp19RF (50 ng: in a total of $10 \mu \mathrm{l}$ ) and the end-repaired HpaII-digested products (1-25 ng) from strain D46 were ligated into SmaI-digested M13mp19RF (50 ng: in a total of $10 \mu \mathrm{l}$ ) with 1 unit T4 DNA ligase (Boehringer), $66 \mathrm{mM}$ Tris/ $\mathrm{HCl}$ ( $\mathrm{pH} 7.5$ ), $5 \mathrm{mM} \mathrm{MgCl}, 1 \mathrm{mM}$ dithiothreitol, $1 \mathrm{mM}$ ATP and incubated at room temperature overnight. Competent JM109 E. coli cells (50 $\mu$; Promega) were transformed with 


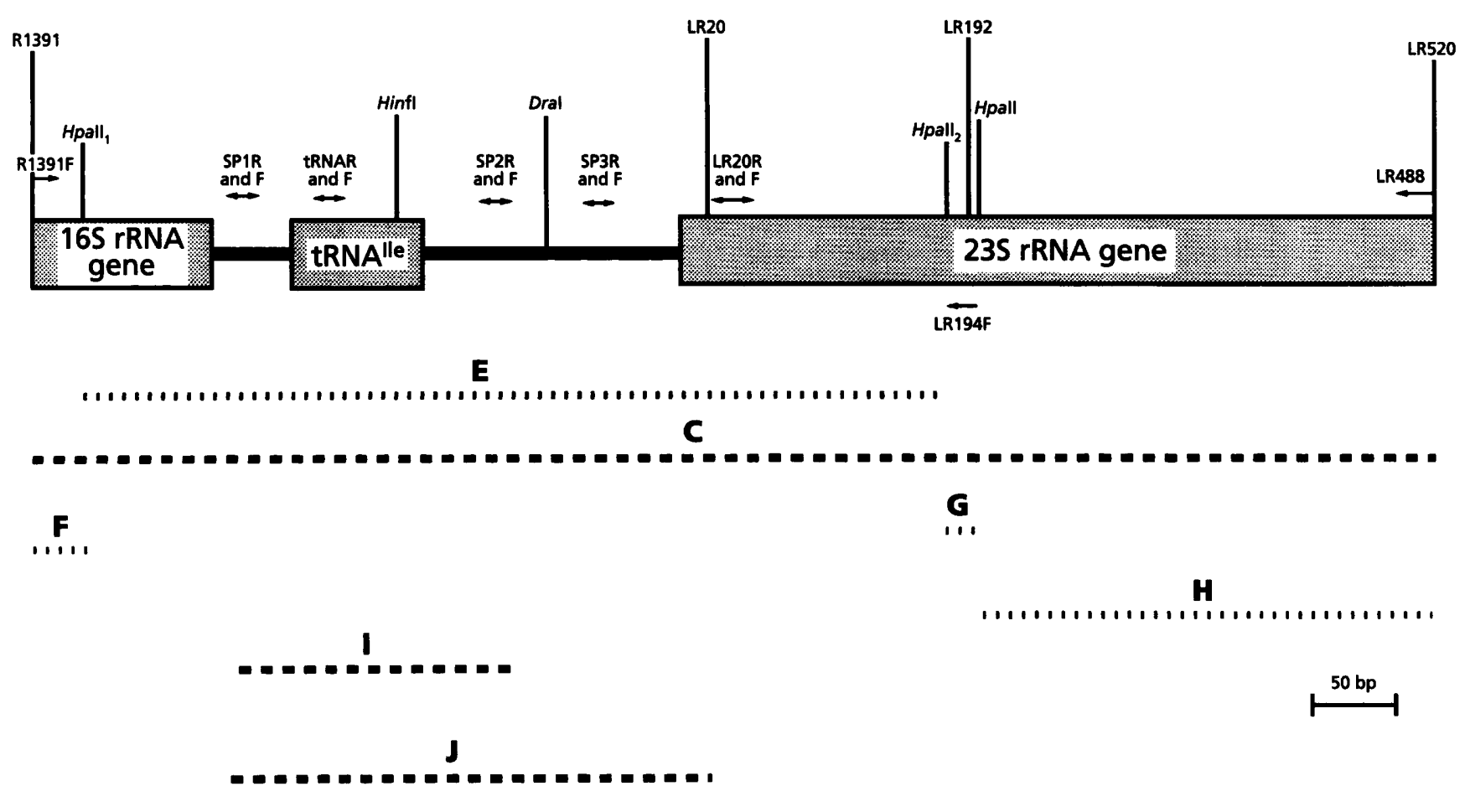

Fig. 1. Approaches for typing and sequencing 16S-23S rDNA alleles in S. aureus. The diagram shows the distribution of rRNA genes and restriction sites in the region of interest. The solid line joining these genes can vary in length in the same strain or in different strains (Fig. 3b). At the bottom of the diagram, the dashed lines show positions of the PCR products C, I and J, which were obtained using the primers R1391F and LR488, SP1F and SP2R, and SP1F and LR20F, respectively (Table 2). The dotted lines show the origins of Hpall fragments (E, F, G and H) obtained from PCR product $C$. The locations of other primer-binding regions that were used to sequence Hpall fragment $\mathrm{E}$ are also shown.

Table 2. Sequencing primers

\begin{tabular}{|c|c|c|c|c|}
\hline Code & Region & Position* & $\begin{array}{c}\text { direction } \\
\text { (sense) }\end{array}$ & Sequence \\
\hline R1391FH† & $16 S$ & $1400-1417^{a}$ & $F(t)$ & GGCCGGTTGTACACACCGCCCGTC \\
\hline $\mathrm{R} 1391 \mathrm{~F}$ & $16 S$ & $1400-1417^{a}$ & $F(+)$ & TTGTACACACCGCCCGTC \\
\hline SP1F & 16S-23S spacer & $51-70^{b}$ & $\mathrm{~F}(+)$ & ATTGTATTCAGTTTTGAATG \\
\hline SP1R & 16S-23S spacer & $51-70^{b}$ & $\mathbf{R}(-)$ & TTACTTACTTATCTAGTTTT \\
\hline TRNAF & tRNA $^{\text {nle }}$ & $100-120^{b}$ & $\mathrm{~F}(+)$ & ATAGCTCAGCTGGTTAGAGC \\
\hline TRNAR & tRNA ${ }^{\text {Ile }}$ & $100-120^{b}$ & $\mathbf{R}(-)$ & GCTCTAACCAGCTGAGCTAT \\
\hline SP2F & 16S-23S spacer & $281-300^{b}$ & $\mathrm{~F}(+)$ & AAAACTAGATAAGTAAGTAA \\
\hline SP2R & 16S-23S spacer & $281-300^{b}$ & $\mathbf{R}(-)$ & GTGGATGCCTTGGCACTAG \\
\hline SP3F & 16S-23S spacer & $390-410^{b}$ & $\mathrm{~F}(+)$ & CACTCACAAGATTAATAACG \\
\hline SP3R & 16S-23S spacer & $390-410^{b}$ & $\mathbf{R}(-)$ & CGTTATTAATCTTGTGAGTG \\
\hline LR20R & $23 \mathrm{~S}$ & $24-42^{c}$ & $\mathrm{~F}(+)$ & GTGGATGCCTTGGCACTAG \\
\hline LR20F & $23 \mathrm{~S}$ & $24-42^{c}$ & $\mathbf{R}(-)$ & CTAGTGCCAAGGCATCCAC \\
\hline LR194F & $23 S$ & $194-214^{c}$ & $\mathrm{R}(-)$ & СTTTCTCTTCTCCGGGTACT \\
\hline LR488 & $23 \mathrm{~S}$ & $502-520^{c}$ & $\mathbf{R}(-)$ & ССTTTCCCTCACGGTACTG \\
\hline $\mathrm{LR} 488 \mathrm{H} \dagger$ & $23 \mathrm{~S}$ & $502-520^{\mathrm{c}}$ & $\mathbf{R}(-)$ & AACCGGCCTTTCCCTCACGGTACTG \\
\hline M13R & Phage M13 & $6205-6221^{d}$ & $\mathrm{~F}(+)$ & CAGGAAACAGCTATGAC \\
\hline M13F & Phage M13 & $6291-6307^{d}$ & $\mathbf{R}(-)$ & GTTTTCCCAGTCACGAC \\
\hline
\end{tabular}

* Numbering according to: $a$, the published 16S rRNA sequence from $S$. aureus (Ludwig et al., 1992); $b$, the aligned spacer sequence for $S$. aureus (Fig. 3); c, the published 23S rRNA sequence from $S$. aureus (Ludwig et al., 1992); $d$, the published sequence for bacteriophage M13. $\dagger$ Addition of $\mathrm{HpaII}$ sites (underlined) at $5^{\prime}$ ends of R1391F and LR488.

$\ddagger$ Sequence obtained from this study. 
(a)

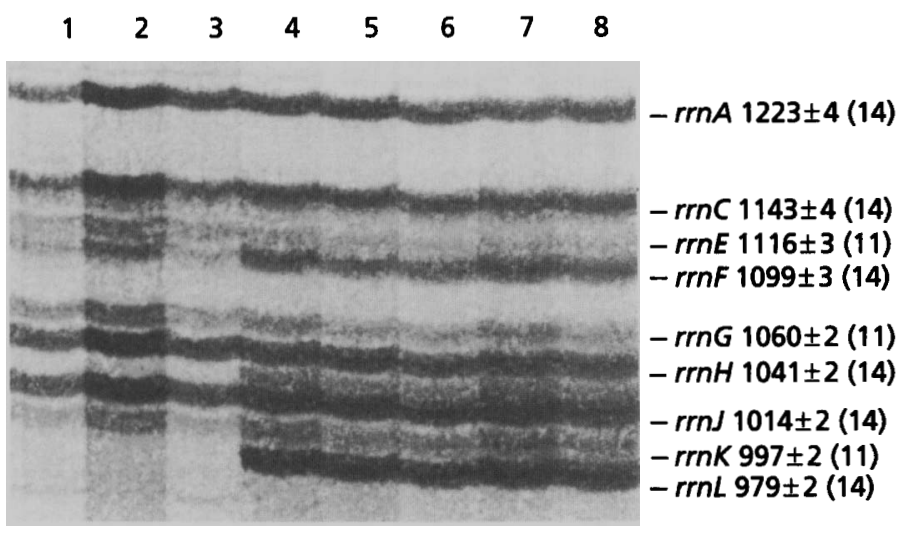

(b)

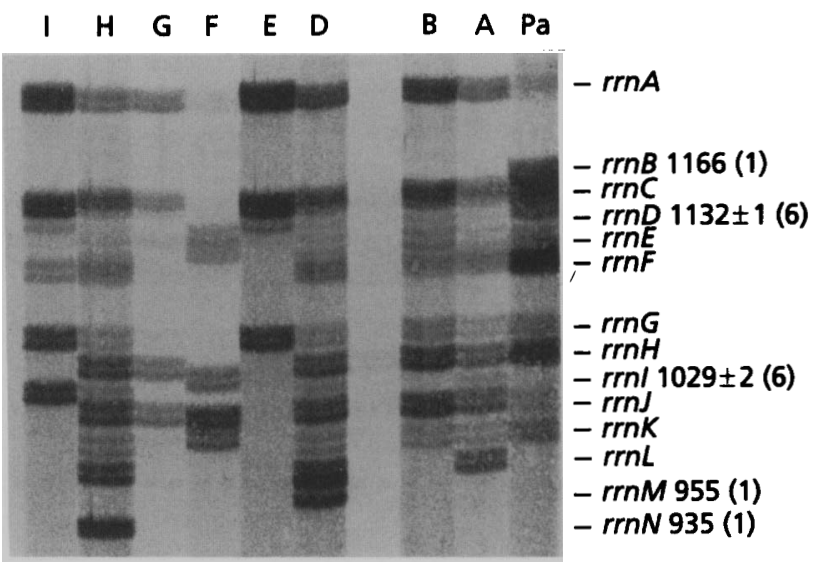

(c)

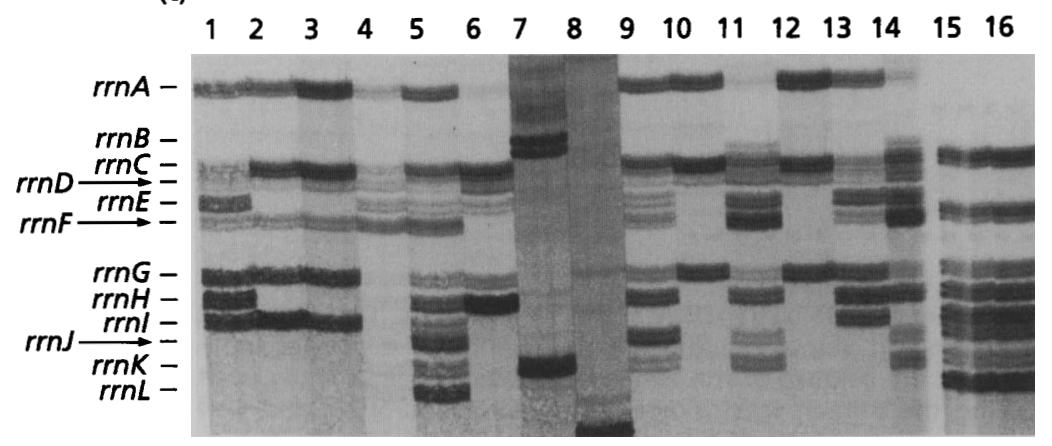

Fig. 2. S. aureus ribotypes. Denaturing PAGE of PCR product $C$ amplified from strains of $S$. aureus. (a) MRSA ribotypes $A$ (lanes 1-3) and B (lanes 4-8). (b) All MRSA ribotypes A-I (excluding C) and penicillin-sensitive ribotype Pa (ATCC 9144). (c) Penicillin- and methicillin-sensitive $S$. aureus strains: lanes $1-6$, ribotypes $\mathrm{Pi}, \mathrm{Pj}, \mathrm{Pj}, \mathrm{Pf}, \mathrm{A}$ (strain $\mathrm{H11}$ ) and $\mathrm{Mg}$; lanes 9-16, ribotypes $\mathrm{B}, \mathrm{Mi}, \mathrm{Mh}, \mathrm{Mi}, \mathrm{Pi}, \mathrm{Mh}, \mathrm{Mj}$ and $\mathrm{Mj}$. The size markers shown in (c) are $\lambda$ DNA digested with HindlII and EcoRI (lane 8; 947 bp band only) and SPP1 DNA digested with EcoRI (lane 7; 1150 and 1000 bp bands only). The sizes (bp) of the respective alleles are shown on the right [mean \pm SEM (number of determinations)].

2-3 $\mu \mathrm{l}$ of the ligation mixtures according to the protocol described in Sambrook et al. (1989). After plates had been incubated overnight at $37^{\circ} \mathrm{C}$, bacteriophage M13 plaques were either picked off and grown in Luria Broth (LB), or colony hybridizations (Sambrook et al., 1989) to HpaII-digested PCR product $\mathrm{C}$ labelled with digoxigenin were performed. Positive plaques were then picked off and grown in LB (Sambrook et al., 1989). Single-stranded bacteriophage M13 DNA was then prepared from all the positive clones (Sambrook et al., 1989). To determine the presence and size of the inserts, the singlestranded DNA from the M13 clones was used as a template in the PCR using M13F and R primers which flank the SmaI and AccI restriction sites (Yanisch-Perron et al., 1985).

DNA sequencing. Sequencing was done by the dideoxynucleotide method of Sanger et al. (1977) using the Bst DNA sequencing kit (Bio-Rad). 7-Deaza-2'-deoxyguanosine triphosphate was used to minimize band compression due to GCrich regions. The primers used for sequencing are listed in Table 2 and Fig. 1.

Data analysis. DNA sequences were processed and analysed by the following methods. The DNASIs program (version 6; Pharmacia) was used to orient, join and edit DNA sequences. The orientation of inserts was deduced by alignment with the $16 \mathrm{~S}$ or $23 \mathrm{~S}$ rDNA sequences from Bacillus subtilis (Green et al., 1985 ) or $S$. aureus (Ludwig et al., 1992). The 17 sequences (fragment E, Fig. 1) were aligned using CLustal v (Higgins et al., 1992) and were aligned to the $16 \mathrm{~S}$ and $23 \mathrm{~S}$ rDNA sequences from $S$. aureus (Ludwig et al., 1992). Further modifications to the alignment were done using MACCLADE software (Maddison \& Maddison, 1992). Phylogenetic analysis was done with the software package PHYLIP using DNAPENNY (Felsenstein, 1993). The resulting treefile was then imported into MACCLADE for further analysis and presentation.

The presence or absence of PCR product $C$ bands was analysed by the protocol of Gürtler (1993) with intense bands reported as positive; when the faint bands were also reported as positive the results did not change.

\section{RESULTS}

\section{Characterization of 16S-235 rDNA spacers}

Using the DNA typing approach used previously (Gürtler, 1993) and the primers LR1391F and LR488, PCR product $C$ (Fig. 1) was amplified from the $S$. aureus strains listed in Table 1. These included 274 MRSA from three geographically distinct clinical sources (261 from the $\mathrm{HRH}$ ) and 45 penicillin- or methicillin-sensitive strains 
Table 3. Presence or absence of sequences within the nine ( $r r n A, C, E, F, G, H, J, K$ and $L$ ) 16S-23S spacer alleles sequenced

The sequence information presented in Fig. 3 is tabulated to show from which $S$. aureus strains the original PCR product was isolated, which clones were characterized, the GenBank accession number, the sizes of the 16S-23S spacer, the HpaII insert (fragment E, see Fig. 1) and fragment $C$, the presence or absence of sequences (CS, conserved sequence; VS, variable sequence; positions and lengths are shown according to numbering in Fig. 3b), and the base-pair differences between clones for the 13 regions.

\begin{tabular}{|c|c|c|c|c|c|c|c|c|c|c|c|c|c|c|c|c|c|c|c|c|}
\hline \multirow[t]{3}{*}{ Allele } & \multirow[t]{3}{*}{ Clone } & \multirow{3}{*}{$\begin{array}{c}\text { Strain } \\
\text { from which } \\
\text { isolated }\end{array}$} & \multirow{3}{*}{$\begin{array}{c}\text { GenBank } \\
\text { no. }\end{array}$} & \multicolumn{3}{|c|}{ Size (bp) of: } & \multicolumn{2}{|c|}{ CS1 tRNA } & vs1 & vs2 & tRNA ${ }^{A h}$ & vs3 & \multirow{2}{*}{\multicolumn{2}{|c|}{$\begin{array}{l}\text { vS4 } \\
\text { Pogition }\end{array}$}} & \multirow[t]{2}{*}{ vs5 } & \multirow[t]{2}{*}{ vs6 } & \multirow[t]{2}{*}{ vS7 } & \multirow[t]{2}{*}{$\operatorname{cs} 3$} & \multirow[t]{2}{*}{ vs8 } & \multirow{3}{*}{$\begin{array}{c}\text { Base- } \\
\text { pair } \\
\text { change }\end{array}$} \\
\hline & & & & $16 \mathrm{~S}-23 \mathrm{~S}$ & Fragment & Fragment & & & & & & & & & & & & & & \\
\hline & & & & spacer & E & $\mathrm{C}^{*}$ & $1-73$ & 93-172 & 74-119 & $120-228$ & $191-266$ & 232-270 & 248-270 & $271-415$ & $416-449$ & $450-527$ & $530-537$ & $538-546$ & $547-550$ & \\
\hline$r m L$ & V13 & H11 & U11775 & 303 & 603 & 981 & + & - & + & - & - & - & + & + & - & - & - & + & - & $\mathrm{NA}$ \\
\hline$r n n K$ & $\mathrm{~V} 41$ & 33952 & U11785 & 319 & 616 & 994 & + & - & + & - & - & + & - & + & - & - & - & + & - & $\mathrm{NA}$ \\
\hline \multirow[t]{5}{*}{ rrnJ } & $\begin{array}{l}4, \\
\text { V4, }\end{array}$ & $\begin{array}{l}\text { D46 } \\
\text { H11 }\end{array}$ & $\begin{array}{l}\text { U11773 } \\
\text { U11783 }\end{array}$ & & & & & & & & & & & & & & & & & \\
\hline & V17, & H11 & U11776 & 335 & 634 & 1012 & + & + & - & - & - & - & - & + & - & - & - & + & - & 5 \\
\hline & V8, & H11 & U11789 & & & & & & & & & & & & & & & & & \\
\hline & V32, & 33952 & U11780 & & & & & & & & & & & & & & & & & \\
\hline & $\sqrt{43}$ & & U11787 & & & & & & & & & & & & & & & & & \\
\hline$r r n H$ & $\begin{array}{l}\text { V27 } \\
\text { V7 }\end{array}$ & $\begin{array}{l}33952 \\
\text { H11 }\end{array}$ & $\begin{array}{l}\text { U11778 } \\
\text { U11788 }\end{array}$ & 362 & $\begin{array}{l}661 \\
663\end{array}$ & $\begin{array}{l}1039 \\
1041\end{array}$ & + & - & + & - & - & + & - & + & + & - & + & + & + & 2 \\
\hline$m n G$ & V2 & H11 & U11777 & 382 & 672 & 1050 & + & + & - & - & - & - & - & + & + & - & + & + & + & NA \\
\hline$r n \mathrm{~F}$ & $\begin{array}{l}\text { V30 } \\
\text { V38 }\end{array}$ & $\begin{array}{l}33952 \\
33952\end{array}$ & $\begin{array}{l}\text { U11779 } \\
\text { U11782 }\end{array}$ & 460 & 756 & 1134 & + & + & - & - & - & - & - & + & + & + & + & + & + & 4 \\
\hline$r r n E$ & V12 & H11 & U11774 & 469 & 764 & 1142 & + & - & + & + & - & + & - & + & + & - & + & + & + & NA \\
\hline$r m C$ & $\begin{array}{l}\text { V } 34 \\
\text { V42 }\end{array}$ & $\begin{array}{l}33952 \\
33952\end{array}$ & $\begin{array}{l}\text { U11781 } \\
\text { U11786 }\end{array}$ & 473 & 774 & 1152 & + & + & - & - & + & - & - & + & + & - & + & + & + & 5 \\
\hline$r r n A$ & V40 & 33952 & U11784 & 551 & 849 & 1227 & + & + & - & - & + & - & - & + & + & + & + & + & + & NA \\
\hline \multicolumn{2}{|c|}{ Length (bp) } & & & & & & 73 & 79 & 33 & 109 & 75 & 38 & 23 & 145 & 33 & 77 & 8 & 8 & 4 & \\
\hline
\end{tabular}

* The size of fragment C (see Fig. 1) can be obtained by adding 331 bp ( $\mathrm{HpaII}_{2}$ to LR520) and $47 \mathrm{bp}$ (R1391 to $\left.H p a \mathrm{II}_{1}\right)$ to fragment E.

from a single Melbourne source; three MRSA and three sensitive strains from type culture collections were used. These strains yielded various amplified products: in total, 15 alleles were recognized (named $r r n A-r r n O$ ), 14 of which are shown in Fig. 2, varying in length from 935 to $1223 \mathrm{bp}$ ( $\mathrm{rrnO}$ was $906 \mathrm{bp}$ in length; not shown).

With the aim of isolating and comparing the variablelength sequences of the 16S-23S rRNA alleles, PCR product C from strains D46 (ribotype B), H11 and ATCC 33952 (both ribotype A) were cleaved with $\mathrm{HpaII}$ and the resulting fragments cloned into M13 vectors. Four clones were isolated from D46, one containing insert $\mathrm{E}$ (Table 3 ), one containing insert $F$, one containing insert $G$ and one containing insert $\mathrm{H}$. Sixteen clones (V2-V17) were isolated from $\mathrm{H} 11$ : seven contained insert $\mathrm{E}$ (Table 3), four contained insert $H$, four contained insert $G$, and one contained insert $\mathrm{F}$. With the sequence information of insert $\mathrm{H}$, primer LR194F was designed, which contained a HpaII site. For strain ATCC 33952, primers LR194F and R1391F were used to obtain a mixture of PCR products, which were digested with $H p a I I$ to yield predominantly product $\mathrm{E}$ and cloned into M13mp19: clones V18-V47 were isolated and nine of these contained insert $\mathrm{E}$ (Table $3)$.

It was confirmed that inserts were of variable length when they were amplified by PCR (not shown) and then digested with DraI or HinfI (not shown; see Fig. 1 for restriction enzyme cleavage sites). It was determined from the first insert sequenced (clone 4) that Hinfl digested at the end of the tRNA ${ }^{\text {Ile }}$ gene (Figs 1 and $3 \mathrm{~b}$ ). All the PCR products which digested with Hinfl (not shown) contained a tRNA ${ }^{\text {Ile }}$ gene, which was subsequently confirmed by DNA sequence data (Fig. 3b).

The designation of alleles (Table 3 ) was made by direct correlation with fragment $\mathrm{C}$ molecular sizes (Fig. 2a). The length of the spacer varied from $303 \mathrm{bp}$ to $551 \mathrm{bp}$ (Table $3)$. The fragment $E$ insert sequences were aligned to the 16S (Fig. 3a), 23S (Fig. 3c) and 16S-23S spacer (Fig. 3b) rDNA sequences. There were only four base-pair differences in the $16 \mathrm{~S}$ rDNA sequences (Fig. 3a), in contrast to 71 base-pair differences in the 23S rDNA sequences (Fig. $3 c$ ). In the $16 \mathrm{~S}-23 \mathrm{~S}$ spacer rDNA (Fig. 3b), Table 3 ) there were no differences in CS1 and CS2; however, there were striking gaps between alleles in regions VS2, tRNA ${ }^{\text {Ala }}$, VS3, VS4, VS5, VS6, VS7 and VS8. The tRNA ${ }^{\text {Ile }}$ gene was present in $r r n J, G, F, C$ and $A$, and the tRNA ${ }^{\mathrm{Ala}}$ gene was only present in $r r n A$ and $C$. The number of base-pair differences between clones judged to be the same allele was five for $r r n J$ (from strains H11, D46 and ATCC 33952, isolated in 1982, 1992 and 1981 respectively), two for $\mathrm{rrH}$ (from strains ATCC 33952 and H11), four for $r r n F$ (strain ATCC 33952) and five for $r r n C$ (ATCC 33952) (Table 3). Using phylogenetic analysis, the $r r n$ alleles were divided 
Table 4. Distribution of alleles in S. aureus ribotypes

PCR product $C$ was amplified from various $S$. aureus strains and separated by denaturing PAGE (Fig. 2). The presence of variable-length alleles $(\operatorname{rrn} A-O)$ is shown. The size of each allele is shown in Fig. 2. The data were collated (using Biolmage Software) from Fig. 2 and four other denaturing polyacrylamide gels.

\begin{tabular}{|c|c|c|c|c|c|c|c|c|c|c|c|c|c|c|c|c|}
\hline \multirow[t]{2}{*}{ Ribotype } & \multicolumn{15}{|c|}{ Allele $(r r n):$} & \multirow{2}{*}{$\begin{array}{l}\text { No. of } \\
\text { isolates }\end{array}$} \\
\hline & $\boldsymbol{A}$ & $\boldsymbol{B}$ & $C$ & $D$ & $E$ & $\boldsymbol{F}$ & $\boldsymbol{G}$ & $\boldsymbol{H}$ & $I$ & $J$ & $\boldsymbol{K}$ & $L$ & $M$ & $\boldsymbol{N}$ & $O$ & \\
\hline \multicolumn{17}{|c|}{$\begin{array}{c}\text { Methicillin } \\
\text { sensitive }\end{array}$} \\
\hline $\mathrm{Ma}$ & + & - & + & - & - & - & + & - & + & - & - & - & - & - & + & 2 \\
\hline $\mathrm{Mb}$ & - & - & + & - & - & - & - & + & - & + & - & + & - & - & - & 1 \\
\hline $\mathrm{Mc}$ & - & - & + & - & - & + & + & + & + & - & - & - & - & - & - & 1 \\
\hline $\mathrm{Md}$ & + & - & - & - & - & + & - & - & - & + & + & + & - & - & - & 1 \\
\hline $\mathrm{Me}$ & - & - & + & + & + & + & - & + & - & + & + & - & - & - & - & 1 \\
\hline $\mathrm{Mf}$ & - & - & + & + & + & + & - & + & - & - & - & - & - & - & - & 1 \\
\hline $\mathrm{Mg}$ & - & - & + & + & + & - & + & + & - & - & - & - & - & - & - & 2 \\
\hline $\mathrm{Mh}$ & - & + & + & + & + & + & - & + & - & + & + & - & - & - & - & 2 \\
\hline Mi & + & - & + & + & - & - & + & + & - & - & - & - & - & - & - & 2 \\
\hline $\mathbf{M j}$ & - & - & + & - & - & + & + & + & + & + & + & + & - & - & - & 2 \\
\hline $\mathrm{Mk}$ & - & - & + & - & - & + & - & + & - & - & - & - & - & - & - & 2 \\
\hline $\mathrm{Ml}$ & + & - & - & - & - & + & - & - & - & + & - & + & - & - & - & 1 \\
\hline $\mathrm{Mm}$ & - & - & + & - & + & + & - & + & - & - & - & - & - & - & - & 1 \\
\hline $\mathrm{Mn}$ & + & + & - & - & - & + & - & - & + & + & - & + & - & - & - & 1 \\
\hline Mo & + & - & + & - & - & + & - & - & + & + & - & + & - & - & - & 1 \\
\hline $\mathrm{Mp}$ & + & - & + & - & - & - & - & + & - & - & - & + & - & - & - & 2 \\
\hline $\mathrm{Mq}$ & + & - & + & + & - & + & + & - & + & - & - & - & - & - & - & 1 \\
\hline \multicolumn{17}{|l|}{$\begin{array}{c}\text { Penicillin } \\
\text { sensitive }\end{array}$} \\
\hline $\mathrm{Pa}$ & - & + & + & + & - & + & - & + & - & - & - & - & - & - & - & 2 \\
\hline Pc & + & - & + & + & + & + & - & - & - & - & - & - & - & - & - & 6 \\
\hline $\mathrm{Pd}$ & + & - & + & + & + & - & + & + & - & + & - & - & - & - & - & 1 \\
\hline $\mathrm{Pe}$ & - & - & + & - & - & + & - & - & - & + & - & + & - & - & - & 1 \\
\hline $\mathrm{Pf}$ & - & - & + & - & - & + & - & + & - & + & - & + & - & - & - & 1 \\
\hline $\mathrm{Pg}$ & - & - & + & - & - & + & + & + & - & - & - & - & - & - & - & 1 \\
\hline $\mathrm{Ph}$ & - & - & + & - & - & + & + & + & - & + & - & + & - & - & - & 1 \\
\hline $\mathrm{Pi}$ & + & - & - & - & + & - & + & + & + & - & - & - & - & - & - & 2 \\
\hline $\mathrm{Pj}$ & + & - & + & - & - & - & + & - & + & - & - & - & - & - & - & 1 \\
\hline \multicolumn{17}{|l|}{ MRSA } \\
\hline$A^{*}$ & + & - & + & - & - & + & - & + & - & + & - & + & - & - & - & 94 \\
\hline $\mathrm{B}+$ & + & - & + & - & - & + & - & + & - & + & - & - & - & - & - & 178 \\
\hline$C \ddagger$ & - & - & + & - & - & + & - & + & - & + & - & - & - & - & - & 3 \\
\hline DS & + & - & + & - & - & + & - & + & - & + & - & + & + & - & - & 1 \\
\hline $\mathrm{E}$ & + & - & + & - & - & - & + & - & - & - & - & - & - & - & - & 1 \\
\hline F & - & - & - & + & - & - & - & - & + & + & + & - & - & - & - & 1 \\
\hline $\mathrm{G}$ & + & - & + & - & - & - & - & + & - & + & - & - & - & - & - & 1 \\
\hline $\mathrm{H}$ & + & - & + & - & - & + & - & + & - & + & - & + & - & + & - & 1 \\
\hline $\mathrm{I} \|$ & + & - & + & - & - & - & + & - & + & - & - & - & - & - & - & 6 \\
\hline
\end{tabular}

* Including H11 and ATCC 33952; one isolate was penicillin-sensitive and another was methicillinsensitive.

† Including D46 and H12; one isolate was methicillin-sensitive.

$\ddagger$ Including $\mathrm{H} 14$.

IIncluding $\mathrm{H} 21$.

|| Five isolates were methicillin-sensitive. 
into three distinct groups (Fig. 4) containing tRNA ${ }^{\text {Ile }}$ and tRNA ${ }^{\text {Ala }}$, $t R N A^{\text {Ile }}$ only, or no tRNA genes.

To confirm the presence of variable-length 16S-23S spacer regions in genomic DNA, PCR products I and J (Fig. 1) were hybridized to genomic DNA isolated from $S$. aureus isolates (not shown). Between four and seven bands, ranging in size from $\sim 600 \mathrm{bp}$ to $\sim 850 \mathrm{bp}$, were obtained for all strains, with variation between strains. The results showed that variable-length $16 \mathrm{~S}-23 \mathrm{~S}$ spacer regions occur in genomic DNA whose size range is similar to the results obtained with PCR-ribotyping (Fig. 2 ) and DNA sequencing (Fig. 3b, Table 3).

\section{Typing of S. aureus strains}

The majority of strains presented in this study were from the HRH (274 strains of a total of 322). Among the MRSA strains, two ribotypes (A and B) that were highly reproducible in individual isolates were obtained (Fig. 2a) with 101 and 180 strains respectively (including five type strains). An additional seven ribotypes were found among the remaining nine MRSA strains (Fig. 2b shows eight MRSA ribotypes). Ribotype A was the major ribotype found (ribotype A/total no. of strains in location) between 1960 and 1989 in Melbourne (19/22), Ireland (9/9), New York (1/1) and the UK (12/12). After 1989, ribotype B was the major ribotype found at the HRH (176 were ribotype $\mathrm{B}$ and 57 were ribotype $\mathrm{A}$ ).

In contrast to the MRSA strains, the sensitive strains showed considerably more variation in the presence or absence of bands, yielding an additional 26 ribotypes from the 48 strains studied (Fig. 2c shows some of these strains). The MRSA ribotypes A, B and I included some of the penicillin- or methicillin-sensitive strains (Table 4). The occurrence of the alleles in the various ribotype classes is summarized in Table 4.

The stability of ribotypes $\mathrm{A}, \mathrm{B}, \mathrm{C}, \mathrm{D}$ and $\mathrm{Pa}$ was investigated by 30 serial passages of strains ATCC 9144, $\mathrm{H} 11, \mathrm{H} 12, \mathrm{H} 14$ and $\mathrm{H} 21$ over a six-week period. The ribotype was assessed after every fifth passage by visual comparison with reference patterns and was found to be stable except for strains $\mathrm{H} 12$ and H21. Strain $\mathrm{H} 12$ was identified as ribotype $\mathrm{B}$ at all passages except number 5, where $r r n L$ appeared, making it ribotype A. Strain H21 was originally found to be ribotype $\mathrm{D}$; however, during the stability experiment it was found to be ribotype $A$ at all passages subsequently investigated (the colonies from which the DNA was prepared were used completely). After plating out colonies from the original frozen stock, genomic DNA was prepared from 10 separate colonies of strain $\mathrm{H} 21$ : in all cases the ribotype was found to be A. The instability of strains $\mathrm{H} 12$ and $\mathrm{H} 21$ could be explained by a contaminant or by the rearrangement, duplication or deletion of an $r r n$ operon to yield $r r n L$ or $r r n M$, respectively. This instability did not affect the typing of $S$. aureus strains significantly since they were infrequent events.

\section{DISCUSSION}

The main finding of the present study was that the presence or absence of specific variable-length rDNA spacer regions varied between $S$. aureus strains. The patterns obtained were mostly stable within strains upon repeated testing, allowed the designation of strains to specific types, discriminated within the species $S$. aureus, and allowed for the easy testing of large numbers of strains. With these criteria met, the molecular typing method described here may be applied to epidemiological studies of $S$. aureus.

The 16S-23S rDNA spacer sequences of nine $r r n$ operons were determined from three MRSA strains. The variation in 16S-23S spacer length (303 bp to $551 \mathrm{bp}$ ) was accounted for by the type (tRNA ${ }^{\text {Ala }}$ or $\mathrm{tRNA}^{\text {tle }}$ ) and number (one, both or none) of tRNA genes and by the presence or absence of other sequences of unknown function.

The type of tRNA gene found in the 16S-23S spacer varies in number $(0,1$ or 2$)$ and combination between operon and between species: Aeromonas bydrophila (East \& Collins, 1993) and E. coli (Morgan et al., 1977) have tRNA ${ }^{\text {Ala }}$, tRNA ${ }^{\text {Ile }}$ and tRNA ${ }^{\text {Glu }}$; Bacillus subtilis (Loughney et al., 1982) and Caulobacter crescentus (Feingold et al., 1985) have $\mathrm{tRNA}^{\text {Ile }}$ and $\mathrm{tRNA}{ }^{\mathrm{Ala}}$; Plesiomonas shigelloides (East et al., 1992) has tRNA ${ }^{\mathrm{Glu}}$; Methanococcus vannielii (Jarsch \& Böck, 1983) and Enterococcus birae (Sechi \& Daneo-Moore, 1993) have tRNA ${ }^{\text {Ala }}$; and Mycobacterium bovis has no tRNA genes (Suzuki et al., 1987). The length of the spacer varies from $156 \mathrm{bp}$ for $M$. vannielii (Jarsch \& Böck, 1983) to 551 bp (this report). There is intraspacer and interspacer variation of other sequences besides tRNA genes (this report).

The variation in length and sequence of the 16S-23S spacer makes it an ideal candidate for typing of strains [ $(C$. difficile (Gürtler, 1993), Mycobacterium avium (Frothingham \& Wilson, 1993, 1994)] and species identification (Jensen et al., 1993) which can potentially be comprehensively applied to the bacterial kingdom.

The instability of $r r n$ operons has been reported in $B$. subtilis (Widom et al., 1988) and E. coli (Hill \& Harnish, 1982). These reports show evidence for the loss of an $r r n$ operon (Loughney et al., 1983; Widom et al., 1988) and recombination leading to chromosomal rearrangement of $r r n$ operons (Hill \& Harnish, 1982). The instability of ribotype D (strain H21) in the present study could be explained by the loss of $r r n M$ giving rise to the stable ribotype A. The relative instability of ribotype B in this study was due to the loss of $r n L$. The frequency of such events is low $\left[\sim 10^{-4}\right.$; Hill \& Harnish (1982)] and thus will have little practical effect on this method.

The fact that ribotypes common to MRSA strains (A, B and I) were also found amongst the sensitive strains suggests that the transfer of $\mathrm{Mec}^{\mathrm{R}}$ to a methicillin- or penicillin-sensitive strain may have occurred; the initial $\mathrm{Mec}^{\mathbf{R}}$ transfer event may have been to a penicillin- 
(a)

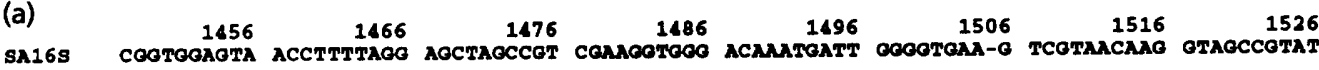

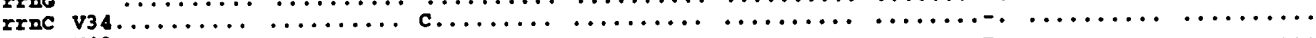

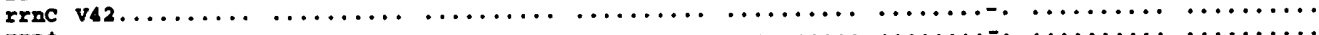
$\operatorname{rrnt}$
$r \times n$

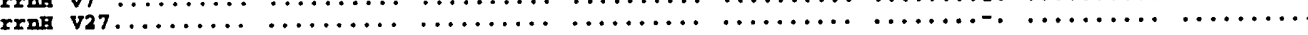

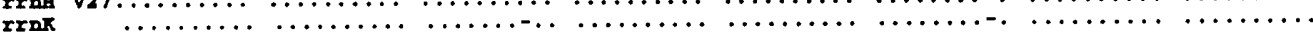

$1536 \quad 1546 \quad 1556$

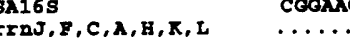

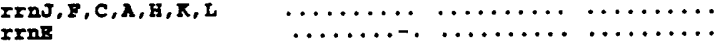

(b)

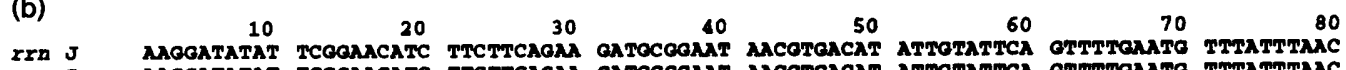

$50 \quad 60$

70

80

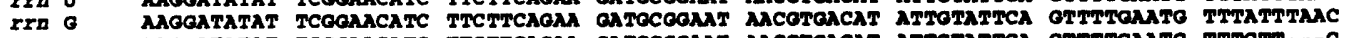
$r \cos$ $\operatorname{rrn} A$

$\operatorname{rrn} F$

$\operatorname{rrn}_{\operatorname{rrn}} \mathrm{B}$

$\operatorname{rrn} x$

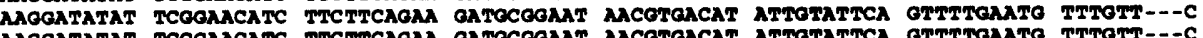

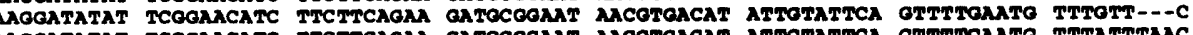

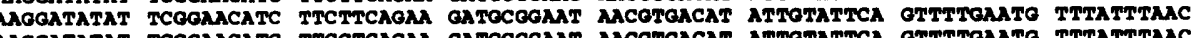

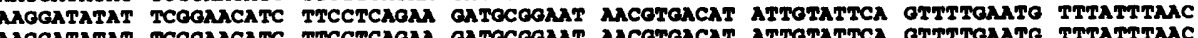

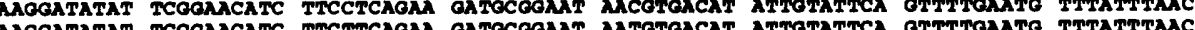

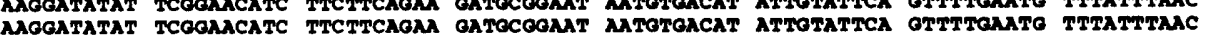

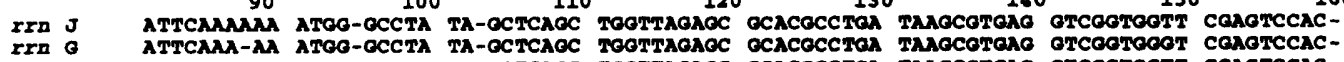

110

120

130

$140 \quad 150$

160

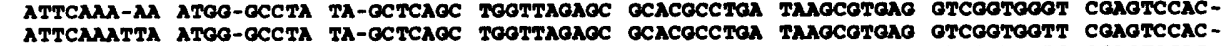

$\operatorname{rrn} A$

$\operatorname{rxn} P$

$\operatorname{rrn} 8$

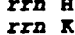

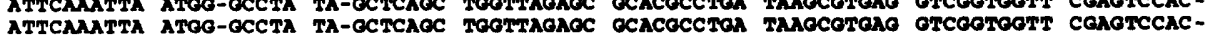

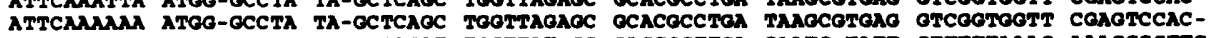

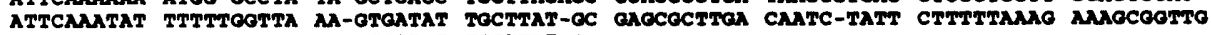

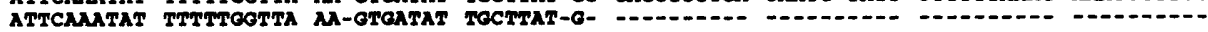

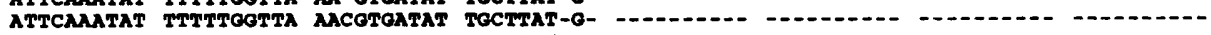

170

180

190

200

210

220

230

240

$\operatorname{rxn} \mathrm{J}$

$\operatorname{rin} 0$

rrn C

$\operatorname{rrn}_{\operatorname{rrn}} \hat{\mathrm{B}}$

Irn B

$\operatorname{rrn} \mathrm{B}$

$\operatorname{rxn} 2$

TTAOCCCCAC CATTA-.-

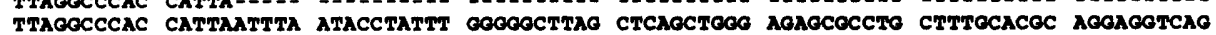

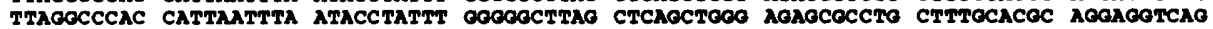

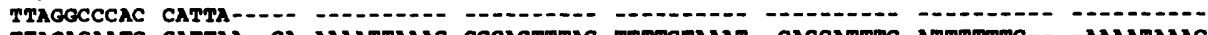

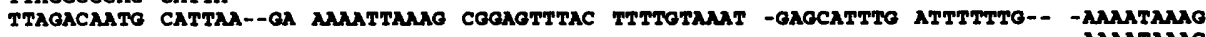
-

$\operatorname{rrn} J$

$\operatorname{rrn} 0$

$\operatorname{rrn} C$

$\operatorname{rrn} A$

$\operatorname{rrn} B$

$\operatorname{rrn} \mathbf{H}$

$\operatorname{rrn} \mathrm{I}$

250

260

270

280

290

300

310

320 .

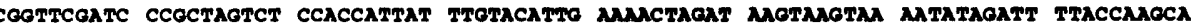

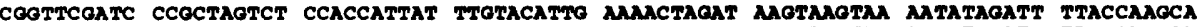
-

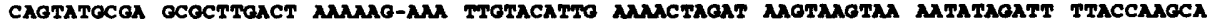

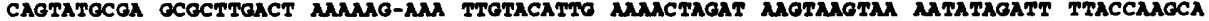

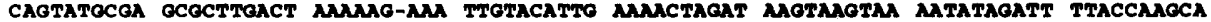

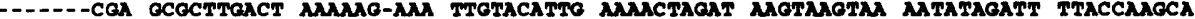

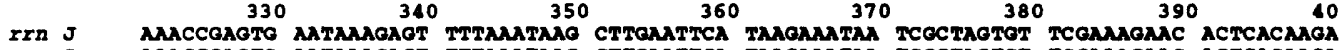

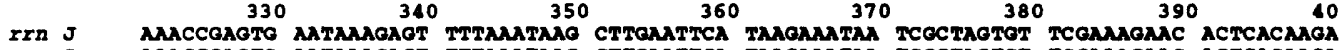

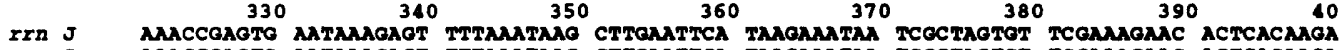

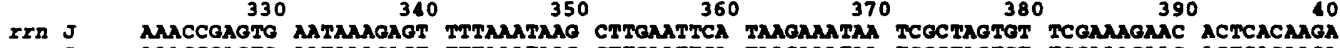

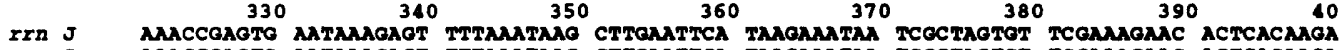

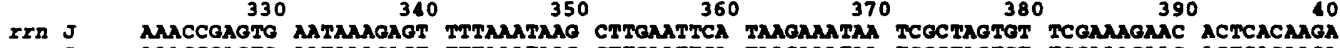

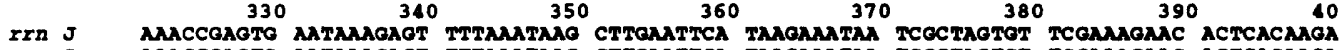

400

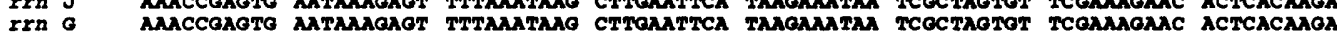

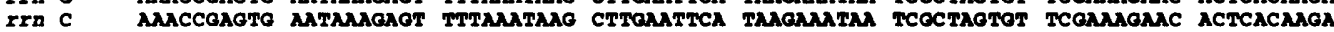
Irn A MAсCCA

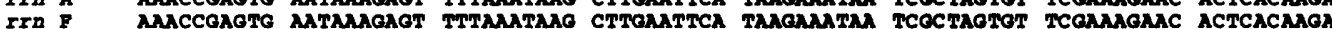

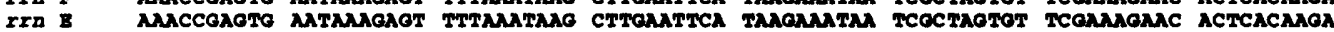

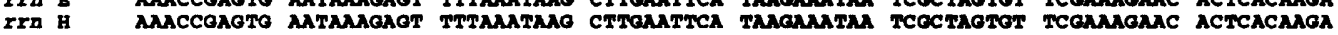

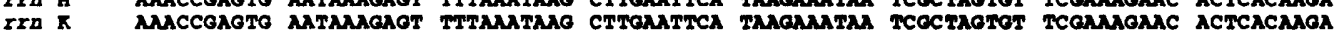

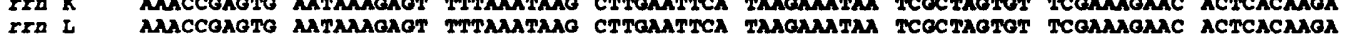

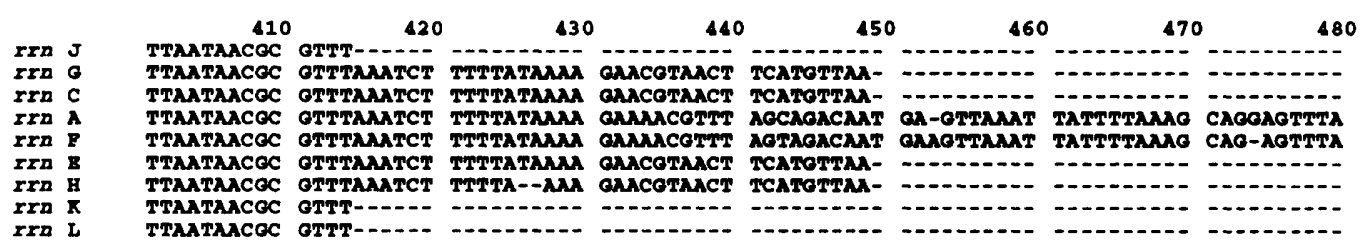

490

500

510

520

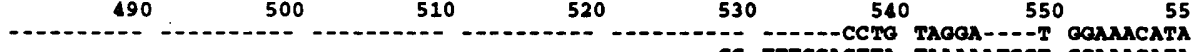
-

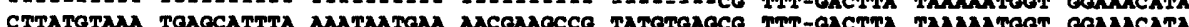

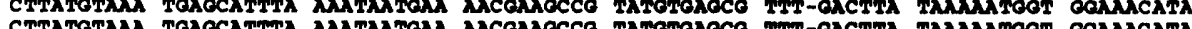

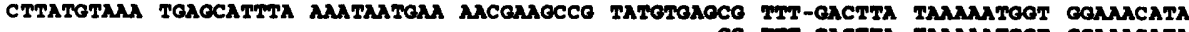
-

Fig. 3. For legend see opposite. 
sensitive strain since the ATCC 8532 strain (from 1953) was ribotype $\mathrm{A}$. The transfer of $\mathrm{Mec}^{\mathrm{R}}$ to $S$. aureus may have occurred by genetic transfer since it has been shown that the mec gene is encoded on a transposon (Trees \& Iandolo, 1988). In support of this are the findings that the mec gene from $S$. aureus and $S$. epidermidis is highly conserved (Ryffel et al. 1990) and that there is significant homology of the mec gene from $S$. aureus and methicillinresistant strains of $S$. baemolyticus and $S$. simulans (Ubukata et al., 1990).

The potential utility of the $S$. aureus typing method described in this study is shown by its application to the typing of MRSA strains, the majority of which were from the HRH. Most of the MRSA strains from the $\mathrm{HRH}$ were ribotype $\mathrm{B}$; however, ribotype A predominated from other parts of the world - significantly the first MRSA isolated in 1960 (Jevons, 1961; Stewart \& Holt, 1963) was ribotype A. The sample size from parts of the world other than Australia in this study is too small to draw firm conclusions; however, the results are consistent with the origin of a single MRSA clone in the early 1960s (Lacey \& Grinsted, 1973). The analysis of strains by multilocus enzyme electrophoresis has demonstrated the occurrence of significant levels of genetic polymorphism among extant MRSA isolates (which also occur in methicillinsensitive strains), leading to the hypothesis that many MRSA organisms have arisen independently (Musser \& Kapur, 1992). Further studies on isolates from continents other than Australia using the method described in this paper may help to confirm this hypothesis.

Whereas the bacteriophage typing system was the standard method for $S$. aureus (Williams et al., 1953), many current MRSA strains are not typable by the International Set of Phages (Richardson et al., 1988), requiring the addition of further experimental phages (Vickery et al., 1993). RFLP analysis by pulsed-field gel electrophoresis has been shown to be more discriminating than phage typing (Schlichting et al., 1993). However, RFLP analysis relies on the stability of restriction enzyme recognition sites such that a point mutation within a site will result in a different RFLP. The sequence conservation of the $r r n$ operons (Woese, 1987) argues for the use of the 16S-23S spacer region as a more stable and direct indicator of the evolutionary divergence of $S$. aureus strains and will be a valuable addition to the large number of typing methods available.

(c)

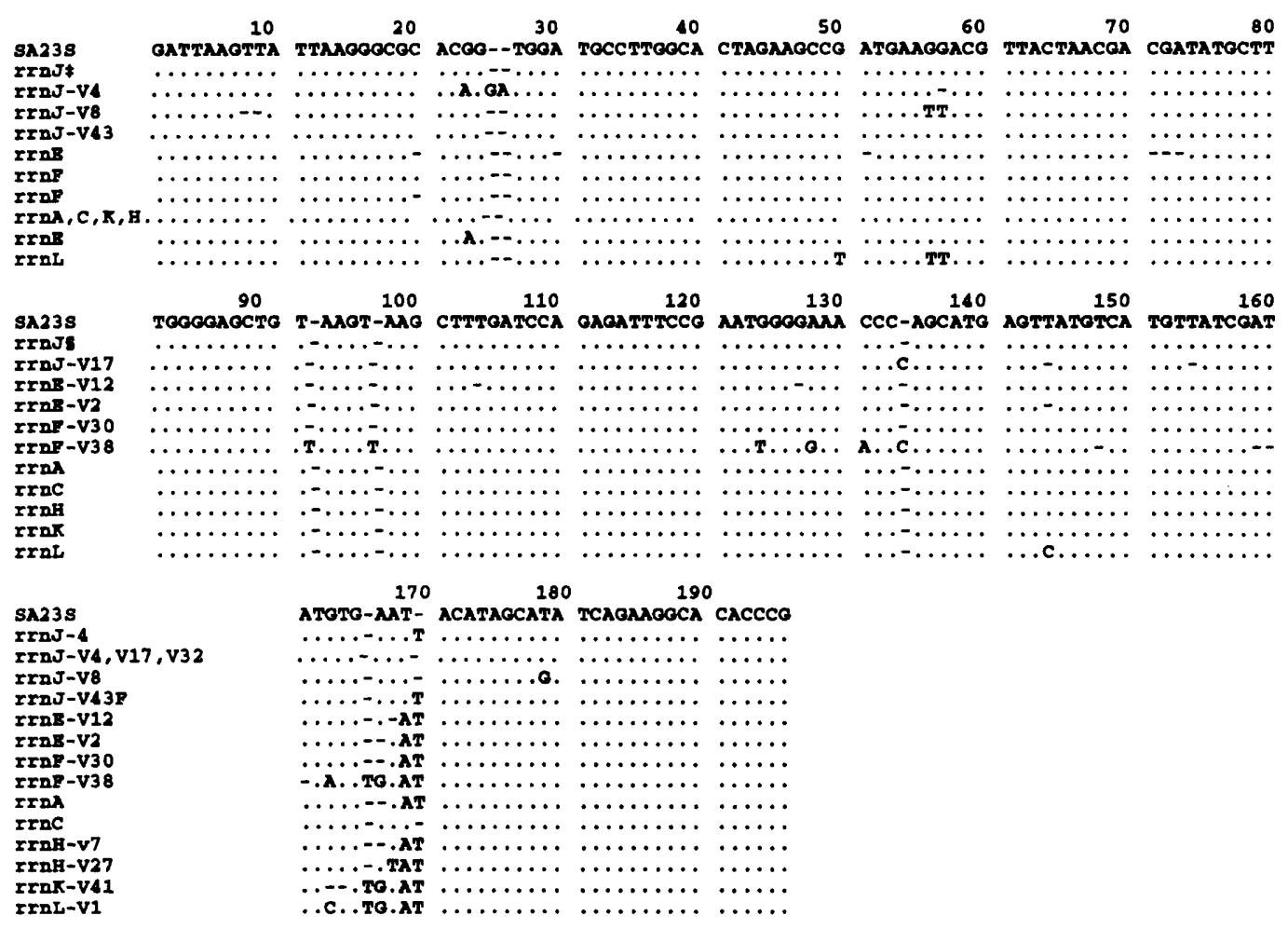

Fig. 3. Alignments of $165-23 S$ spacer sequences from S. aureus. Fragment E from S. aureus strains (Table 3 ) was cloned into M13mp18RF and sequenced with the primers listed in Table 2 and Fig. 1. The sequences were derived from the clones and isolates listed in Table 3. The sequences SA16S and SA23S were taken from Ludwig et al. (1992). Shown is the alignment of $r r n$ alleles with SA16S (a), of $r$ rnA with $r r n C, E, F, G, H, J, K$, and $L$ (b), and of $r r n$ alleles with SA23S (c). The symbols refer to an identical base (.) and an absent base $(-)$. $\dagger=r r n A, E, J, L, F ; \ddagger=$ clones $4, V 17, V 32 ; \S=$ clones $3, V 4$, V8, V32, V43. 


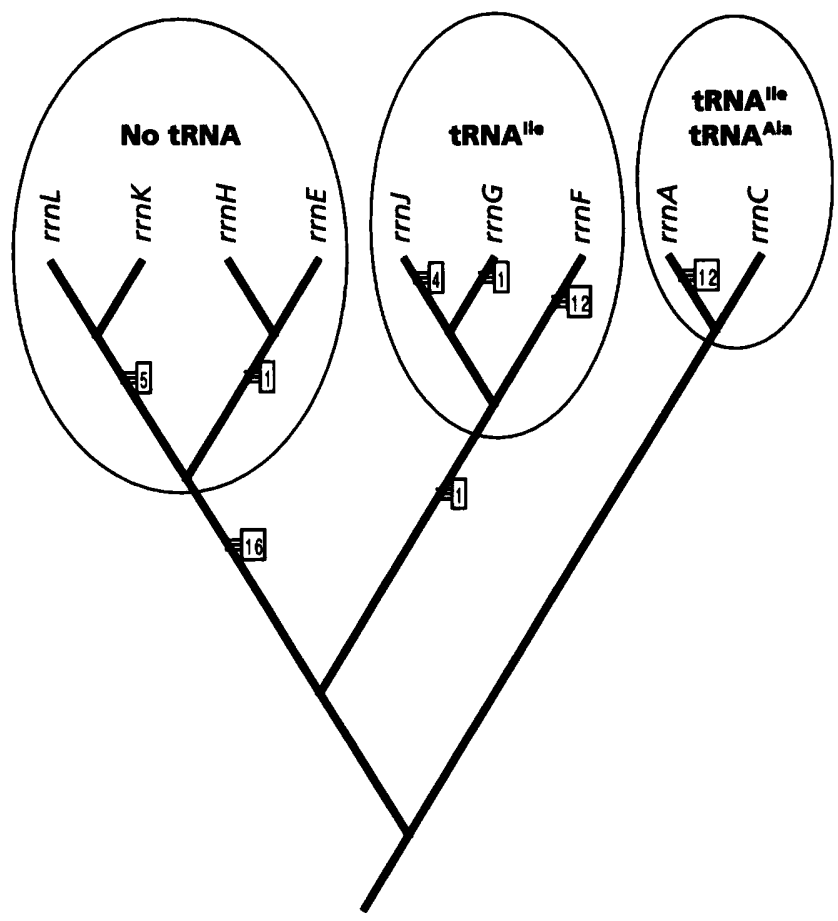

Fig. 4. Dendrogram showing the relationships of the 16S-23S alleles. The same tree was obtained using the data from either Fig. 3(b) or Table 3. One parsimonious tree was obtained with DNAPENNY from the PHYLIP package. Then, using MACCLADE, of the 16 possible rerootings, the tree shown was used because it was drawn using the longest allele $\operatorname{rrn} A$ as the root. The numbers show the number of nucleotide changes per branch.

\section{ACKNOWLEDGEMENTS}

We would like to thank Drs B. C. Mayall and V. A. Stanisich, and Ms. V.A. Wilson, for helpful discussions. We thank Professor W. B. Grubb for supplying us with bacterial strains. We would like to thank the Department of Veterans' Affairs for permission to publish this paper.

\section{REFERENCES}

Amikam, D., Glaser, G. \& Razin, S. (1984). Mycoplasmas (Mollicutes) have a low number of rRNA genes. J Bacteriol 158, 376-378.

Bercovier, H., Kafri, O. \& Sela, S. (1986). Mycobacteria possess a surprisingly small number of ribosomal RNA genes in relation to the size of their genome. Biocbim Biophys Res Commun 136, 1136-1141.

Blair, J. E. \& Williams, R. E. O. (1961). Phage typing of staphylococci. Bull WHO 24, 771-784.

Blumberg, H. M., Rimland, D., Kiehlbauch, J. A., Terry, P. M. \& Wachsmuth, I. K. (1992). Epidemiologic typing of Stapbylococcus aureus by DNA restriction fragment length polymorphisms of rRNA genes: elucidation of the clonal nature of a group of bacteriophage-nontypeable, ciprofloxacin-resistant, methicillinsusceptible $S$. aureus isolates. J Clin Microbiol 30, 362-369.

Cookson, B., Talsania, H., Naidoo, J. \& Phillips, I. (1986). Strategies for typing and properties of epidemic methicillin-resistant Stapbylococcus aureus. Eur J Clin Microbiol 5, 702-709

Costas, M., Cookson, B. D., Talsania, H. G. \& Owen, R. J. (1989). Numerical analysis of electrophoretic protein patterns of methicillin-resistant strains of Staphylococcus aureus. J Clin Microbiol 27, 2574-2581.

De Buyser, M.-L., Morvan, A., Aubert, S., Dilasser, F. \& El Solh, N. (1992). Evaluation of a ribosomal RNA gene probe for the identification of species and subspecies within the genus Stapbylococcus. J Gen Microbiol 138, 889-899.

East, A. K. \& Collins, M. D. (1993). Molecular characterization of DNA encoding 23S rRNA and 16S-23S rRNA intergenic spacer regions of Aeromonas bydrophila. FEMS Microbiol Lett 106, 129-133.

East, A. K., Allaway, D. \& Collins, M. D. (1992). Analysis of DNA encoding $23 \mathrm{~S}$ rRNA and 16S-23S rRNA intergenic spacer regions from Plesiomonas shigelloides. FEMS Microbiol Lett 74, 57-62.

Feingold, J., Bellofatto, V., Shapiro, L. \& Amemiya, K. (1985). Organization and nucleotide sequence analysis of an rRNA and tRNA gene cluster from Caulobacter crescentus. J Bacteriol 163, 155-166.

Felsenstein, J. (1993). PHYLIP (Phylogeny Inference Package) Version 3.5p. Department of Genetics, University of Washington, Seattle.

Frothingham, R. \& Wilson, K. H. (1993). Sequence-based differentiation of strains in the Mycobacterium avium complex. $J$ Bacteriol 175, 2818-2825.

Frothingham, R. \& Wilson, K. H. (1994). Molecular phylogeny of the Mycobacterium avium complex demonstrates clinically meaningful divisions. J Infect Dis 169, 305-312.

Garnier, T., Canard, B. \& Cole, S. T. (1991). Cloning, mapping, and molecular characterization of the rRNA operons of Clostridium perfringens. J Bacteriol 173, 5431-5438.

Green, C. J., Stewart, G. C., Hollis, M. A., Vold, B. S. \& Bott, K. F. (1985). Nucleotide sequence of the Bacillus subtilis ribosomal RNA operon, rrnB. Gene 37, 261-266.

Gurtler, V. (1993). Typing of Clostridium difficile strains by PCRamplification of variable length $16 \mathrm{~S}-23 \mathrm{~S}$ rDNA spacer regions. $J$ Gen Microbiol 139, 3089-3097.

Gurtler, V., Wilson, V. A. \& Mayall, B. C. (1991). Classification of medically important clostridia using restriction endonuclease site differences of PCR-amplified 16S rDNA. J Gen Microbiol 137, 2673-2679.

Hartstein, A. I., Morthland, V. H., Eng, S., Archer, G. L., Schoenknecht, F. D. \& Rashad, A. L. (1989). Restriction enzyme analysis of plasmid DNA and bacteriophage typing of paired Staphylococcus aureus blood culture isolates. J Clin Microbiol 27, 1874-1879.

Harvey, S., Hill, C. W., Squires, C. \& Squires, C. L. (1988). Loss of the spacer loop sequence from the $r r n \mathrm{~B}$ operon in the Escherichia coli $\mathrm{K}-12$ subline that bears the $\operatorname{rel} A 1$ mutation. $J$ Bacteriol 170, 1235-1238.

Higgins, D. G., Bleasby, A. J. \& Fuchs, R. (1992). Clustal v: improved software for multiple sequence alignment. Comput $A p p l$ Biosci 8, 189-191.

Hill, C. W. \& Harnish, B. W. (1982). Transposition of a chromosomal segment bounded by redundant rRNA genes into other rRNA genes in Escherichia coli. J Bacteriol 149, 449-457.

Jarsch, M. \& Bbck, A. (1983). DNA sequence of the $16 \mathrm{~S} r \mathrm{RNA} / 23 \mathrm{~S}$ rRNA intercistronic spacer of two rDNA operons of the archaebacterium Metbanococcus vannielii. Nucleic Acids Res 11, 7537-7544.

Jensen, M. A., Webster, J. A. \& Straus, N. (1993). Rapid identification of bacteria on the basis of polymerase chain reactionamplified ribosomal DNA spacer polymorphisms. Appl Environ Microbiol 59, 945-952.

Jevons, M. P. (1961). 'Celbenin'-resistant staphylococci. Br Med J 1, 124-125. 
Kloos, W. E. \& Schleifer, K. H. (1986). Genus IV. Staphylococcus Rosenbach 1884, $18^{\mathrm{AL}}$ (Nom. Cons. Opin. 17 Jud. Comm. 1958, 153). In Bergey's Manual of Systematic Bacteriology, vol. 2, pp. 1013-1035. Edited by P. H. A. Sneath, N. S. Mair, M. E. Sharpe \& J. G. Holt. Baltimore: Williams \& Wilkins.

Kreiswirth, B., Kornblum, J., Arbeit, R. D., Eisner, W., Maslow, J. N., McGeer, A., Low, D. E. \& Novick, R. P. (1993). Evidence for a clonal origin of methicillin resistance in Stapbylococcus aureus. Science 259, 227-230.

Lacey, R. W. \& Grinsted, J. (1973). Genetic analysis of methicillinresistant strains of Stapbylococcus aureus: evidence for their evolution from a single clone. J Med Microbiol 6, 511-526.

Loughney, K., Lund, E. \& Dahlberg, J. E. (1982). tRNA genes are found between 16S and 23S rRNA genes in Bacillus subtilis. Nucleic Acids Res 10, 1607-1624.

Loughney, K., Lund, E. \& Dahlberg, J. E. (1983). Deletion of an rRNA gene set in Bacillus subtilis. J Bacteriol 154, 529-532.

Ludwig, W., Kirchof, G., Klugbauer, N., Weizenegger, N., Betzl, D., Ehrmann, M., Hertel, C., Jilg, S., Tatzel, R., Zitzelsberger, H., Liebl, S., Hochberger, M., Shah, J., Lane, D. \& Wallnoef, P. R. (1992). Complete 23S ribosomal RNA sequences of gram-positive bacteria with a low DNA G + C content. Syst Appl Microbiol 15, 487-501.

Maddison, W. P. \& Maddison, D. R. (1992). MacClade, analysis of phylogeny and character evolution. Version 3.0. Sunderland, MA: Sinauer Associates.

Monzon, M. C., Aubert, S., Morvan, A. \& El Solh, N. (1991). Usefulness of three probes in typing isolates of methicillin-resistant Stapbylococcus aureus (MRSA). J Med Microbiol 35, 80-88.

Morgan, E. A., Ikemura, T. \& Nomura, M. (1977). Identification of spacer tRNA genes in individual ribosomal RNA transcription units of Escherichia coli. Proc Natl Acad Sci USA 74, 2710-2714.

Mulligan, M. E., Kwok, R. Y., Citron, D. M., John, J. J. \& Smith, P. B. (1988). Immunoblots, antimicrobial resistance, and bacteriophage typing of oxacillin-resistant Staphylococcus aureus. J Clin Microbiol 26, 2395-2401.

Musser, J. M. \& Kapur, V. (1992). Clonal analysis of methicillinresistant Stapbylococcus aureus strains from intercontinental sources: association of the mec gene with divergent phylogenetic lineages implies dissemination by horizontal transfer and recombination. $J$ Clin Microbiol 30, 2058-2063.

Nakagawa, T., Uemori, T., Asada, K., Kato, I. \& Harasawa, R. (1992). Acholeplasma laidlawii has tRNA genes in the 16S-23S spacer of the rRNA operon. J Bacteriol 174, 8163-8165.

Paithankar, K. R. \& Prasad, K. S. N. (1991). Precipitation of DNA by polyethylene glycol and ethanol. Nucleic Acids Res 19, 1346.

Preheim, L., Pitcher, D., Owen, R. \& Cookson, B. (1991). Typing of methicillin-resistant and susceptible Stapbylococcus aureus strains by ribosomal RNA gene restriction patterns using a biotinylated probe. Eur J Clin Microbiol \& Infect Dis 10, 428-436.

Prevost, G., Pottecher, B., Dahlet, M., Bientz, M., Mantz, J. M. \& Piemont, Y. (1991). Pulsed-field gel electrophoresis as a new epidemiological tool for monitoring methicillin-resistant Stapbylococcus aureus in an intensive care unit. J Hosp Infect 17, 255-269.

Richardson, J. F., Chittasobhon, N. \& Marples, R. R. (1988). Supplementary phages for the investigation of strains of methicillinresistant Staphylococcus aureus. J Med Microbiol 25, 67-74.

Ryffel, C., Tesch, W., Birch-Machin, I., Reynolds, P. E., BarberisMaino, L., Kayser, F. H. \& Berger-Bächi, B. (1990). Sequence comparison of $\operatorname{mec} A$ genes isolated from methicillin-resistant Stapbylococcus aureus and Stapbylococcus epidermidis. Gene 94, 137-138.

Sambrook, J., Fritsch, E. F. \& Maniatis, T. (1989). Molecular Cloning: a Laboratory Manual, 2nd edn. Cold Spring Harbor, NY: Cold Spring Harbor Laboratory.

Sanger, F., Nicklen, S. \& Coulsen, A. R. (1977). DNA sequencing with chain-terminating inhibitors. Proc Natl Acad Sci USA 74, 5463-5467.

Schlichting, C., Branger, C., Fournier, J. M., Witte, W., Boutonnier, A., Wolz, C., Goullet, P. \& Doring, G. (1993). Typing of Stapbylococcus aureus by pulsed-field gel electrophoresis, zymotyping, capsular typing, and phage typing: resolution of clonal relationships. J Clin Microbiol 31, 227-232.

Sechi, L. A. \& Daneo-Moore, L. (1993). Characterization of intergenic spacers in two $r r n$ operons of Enterococcus hirae ATCC 9790. J Bacteriol 175, 3213-3219.

Stephenson, J. R., Crook, S. J. \& Tabaqchali, S. (1986). New method for typing Stapbylococcus aureus resistant to methicillin based on sulphur-35 methionine labelled proteins, its application in an outbreak. Br Med J Clin Res 293, 581-583.

Stewart, G. T. \& Holt, R. J. (1963). Evolution of natural resistance to the newer penicillin. $\mathrm{Br}$ Med J 1, 308-311.

Suzuki, Y., Yoshinaga, K., Ono, Y., Nagata, A. \& Yamada, T. (1987). Organization of rRNA genes in Mycobacterium bovis BCG. $J$ Bacteriol 169, 839-843.

Townsend, D. E., Ashdown, N., Bradley, J. M., Pearman, J. W. \& Grubb, W. B. (1984). 'Australian' methicillin-resistant Stapbylococcus aureus in a London hospital? Med J Aust 141, 339-340.

Townsend, D. E., Ashdown, N., Bolton, S., Bradley, J., Duckworth, G., Moorhouse, E. C. \& Grubb, W. B. (1987). The international spread of methicillin-resistant Stapbylococcus aureus. J Hosp Infect 9, 60-71.

Trees, D. L. \& Iandolo, J. J. (1988). Identification of a Staphylococcus aureus transposon ( $\operatorname{Tn} 4291)$ that carries the methicillin resistance gene(s). J Bacteriol 170, 149-154.

Ubukata, K., Nonoguchi, R., Song, M. D., Matsuhashi, M. \& Konno, M. (1990). Homology of mec $A$ gene in methicillin-resistant Stapbylococcus baemolyticus and Stapbylococcus simulans to that of Stapbylococcus aureus. Antimicrob Agents Chemother 34, 170-172.

Vickery, A. M. \& the Australian Group for Antimicrobial Resistance (1993). Strains of methicillin-resistant Staphylococcus aureus isolated in Australian hospitals from 1986 to 1990. J Hosp Infect 24, 139-151.

Wei, M. Q. \& Grubb, W. B. (1992). Typing of Australian methicillin-resistant Stapbylococcus aureus strains by pulsed field gel electrophoresis. J Med Microbiol 37, 187-191.

Widom, R. L., Jarvis, E. D., LaFauci, G. \& Rudner, R. (1988). Instability of rRNA operons in Bacillus subtilis. J Bacteriol 170, 605-610.

Williams, R. E. O., Rippon, J. E. \& Dowsett, L. M. (1953). Bacteriophage typing of strains of Stapbylococcus aureus from various sources. Lancet i, 510-514.

Woese, C. R. (1987). Bacterial evolution. Microbiol Rev 51, 221-271.

Yanisch-Perron, C., Vieira, J. \& Messing, J. (1985). Improved M13 phage cloning vectors and host strains: nucleotide sequences of the M13mp18 and pUC19 vectors. Gene 33, 103-119.

Received 31 August 1994; revised 28 November 1994; accepted 3 January 1995. 